
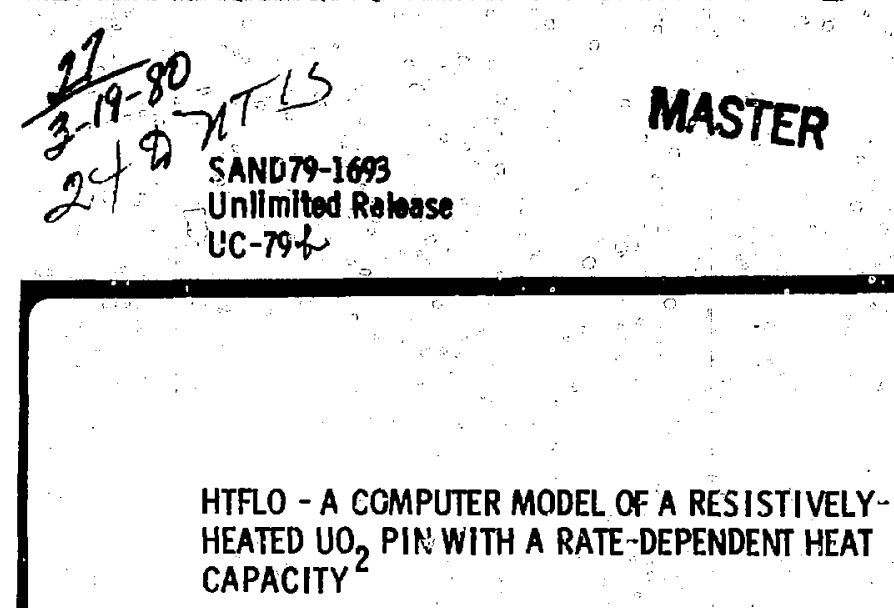

John E. Smaardyk 
CONTENTS

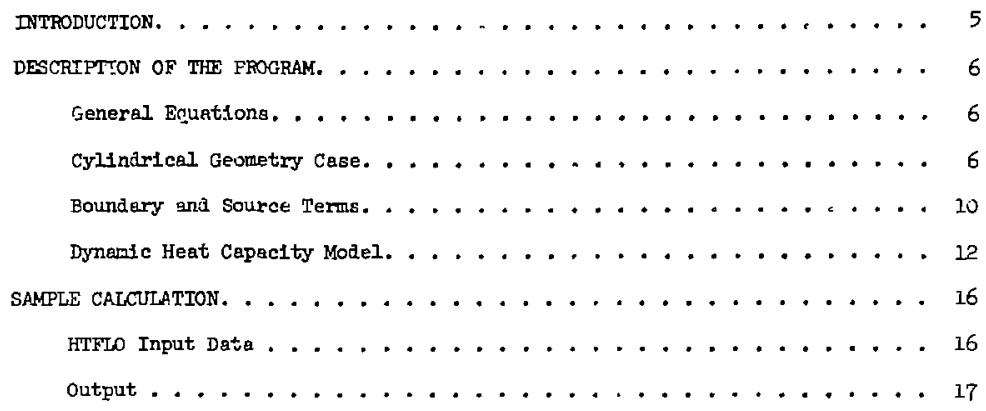

ADPENDIX A - Thermal Properties of UO $\mathrm{U}_{2}$ Used in HTFLO. . . . . . . 18

APPENDIX B - FORTRAN L1sting of HTYLO for CDC7600 . . . . . . . . . . 20

APPENDIX C - Sample Calculation Using HTFLO . . . . . . . . . . . 26

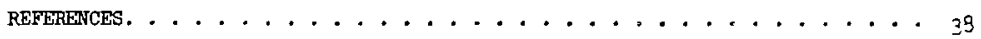


LIST OF MIGURE;

Figure 1. Cylindifical geonetry and Indexding corvertion . . . . . . . . . 7

Figure 2. Two modelg for the heat capacity of soltd $\mathrm{UO}_{2}{ } \ldots \ldots \ldots$

FI gure 3. Illustration of temperature,enthalpy history for one zone during a single time steg .................. 14

Flgure 4. Input data cards for the aample HIFL calculation. . . . . . . 27 
A one-dfmensionel model, HLFL, has been deviloped to desertbe the thermal behavior of a uranium dioxdde $\left(\mathrm{UO}_{2}\right)$ rod that is heated resistively and cooled by ourface radiation. The heat transfer portion of the program is a forwacd afferencing scheme based on OHEDTM. (I) The major alfferences are that HIFLO Incorporates a dynamic heat capacity model, the sample's temperature-dependent electrical properties are calculated for each time step and corrections are included for the cylindrical geometry. The dyaamic beat capacity model used in HTFL is empirfcel with an adjustable relaxation time constant. A mor: detalled theoretical model which treats the dymamic heat capacity on a microscople scele based on real physical considerations has also been developed recently. (2)

This model was developed to ald in desigring an experiment to measure the heat capacity of $\mathrm{UO}_{2}$ during rapla resistive heating. 1 major limitation to this technisie arlses from the increase in electrical conductivity as the temperature riges. This can lead to an unstable beating mode in which a hot fllement buslas up in the sample's Interfor. HTFL has been used to assess the fensibility of a serles of experimental conflgurations.

This report describes the fintte difserence equations used, the treatment of the source and buundary terms, and the dynamic enthalpy model. Detafled input instructions are provided and a semple calculation is shown. 
DESCRIPIIOK OF THE FROGRA

\section{General Equationa}

The program solves the general heat conduetion equation for the case in which the modeled pin is divided Iuto ungy concentric zones, the teuperature for each of whint is governed by the followng equetion: (5)

$$
\nabla \cdot(L \nabla T)+\dot{q}=\text { oc } \frac{\partial T}{\partial t} \text {. }
$$

T 1s the temperature of the zone and $q$ is the heat generation rate per ualt volume, and $k, \rho$ and $c$ are the thermal conductivity, density and speciflc heat, reapectively.

The boundary conditions impoed on Equation (I) are the continulty of temperatiare and heat flux at the boundaries of each zone. The taitial condition is the sample's temperature prafile at zero time.

\section{Cylindrical Geometry Cage}

The one-dimensional form of equation (1) can be written in cylindrical coordsrates es

$$
\mathbf{k}\left(\frac{\partial^{2} T}{\partial r^{2}}+\frac{1}{r} \frac{\partial r}{\partial r}\right)+\dot{q}=p c \frac{\partial r}{\partial t}
$$

where $k$ is assumed to be a slowly varylng funetion of $r$.

To solve this equation ualng a flnite difference technique, the sample is divided Into N, equaily spaced, redial 2ones. The sample's length and diameter are $L$ cind $D$, respectively. For the one-dimenglonal problem there 1 s no variation of tempersture, properties or geonetry in the axdal or angular dimensions. Flgure I 117ustrates the geometry and zone numbering convention. Note that the outerwost zone 1s labeled $I=1$.

The flrst term in equation (2) is the net rate heat is conducted into a glven zone. Applytug the Divergence Theorem Helds Fourler's Law:

$$
-k \frac{\partial T}{\partial r}=\dot{q}_{B}
$$




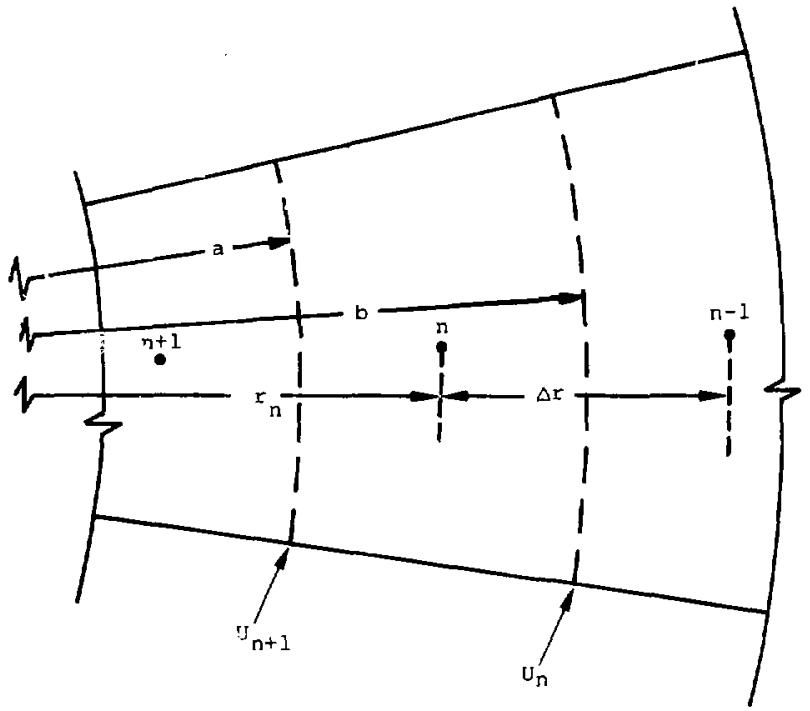

- CENTERLINE

SURFACE

Flgure 1. Cylindriegl geometry and indexing convention. To gimplify the fugure, only a segwent of the entire cylinder is abown. 
where $\dot{q}_{s} 18$ the surfece heat flux. For a hollow cylinder of inner radius a and outer radius $b$, equation (3) is solved by

$$
T=\frac{T_{a}-T_{b}}{\ln \left(\frac{a}{b}\right)} \ln r+\text { const. }
$$

Using this expression for $T$, equation (3) becomes:

$$
\dot{q}_{s}=-\frac{k}{r \ln \frac{a}{b}}\left(T_{a}-T_{b}\right)
$$

Equation (5) is expressed in terms of the zone boundary temperatures. A more conventent form for calculations would be in terms of the node temperatures. To do this, first consider the heat flux througin the right half (as depicted in figure (I)) of zone $\mathrm{n}$ :

$$
\dot{q}_{s}=-\frac{k_{n}}{r \ln \frac{b}{r_{b}}}\left(T_{n}-T_{b}\right)
$$

The thermel conductivity is subscripted since it can have afferent values in each zone.

Next, consider the heat flux through the left half of zone $n-1$ :

$$
\dot{q}_{a}=-\frac{k_{n-1}}{r \ln \frac{r_{n-1}}{b}}\left(T_{b}-T_{n-1}\right)
$$

$\dot{q}_{g} 1$ s the same in equations (6) and (7) as required by the boundary condition of continuous beat flux. These equations can be solved for the surface tempersture $\left(T_{b}\right)$ at $r=b:$ 


$$
T_{b}=\frac{\frac{k_{n} T_{n}}{\ln \left(\frac{b}{r_{n}}\right)}+\frac{k_{n-1} T_{n-1}}{\ln \left(\frac{r_{n-1}}{b}\right)}}{\frac{k_{n}}{\ln \left(\frac{b}{r_{n}}\right)}+\frac{k_{n-1}}{\ln \left(\frac{r_{n-1}}{b}\right)}}
$$

Substituting this expression for $\mathrm{T}_{\mathrm{b}}$ into equation $(6)$ and reairanging gives

$$
\dot{q}_{s}=-\frac{1}{r}\left(\frac{\ln \left(\frac{b}{r_{n}}\right)}{k_{n}}+\frac{\ln \left(\frac{r_{n-1}}{b}\right)}{k_{n-1}}\right)^{-1}\left(T_{n}-T_{n-1}\right)
$$

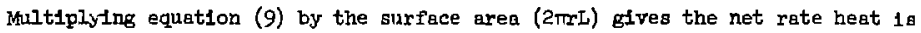
conducted exom zone n into zone n-li

$$
\dot{a}_{R}=-\left(\frac{\ln \left(\frac{b}{r_{n}}\right)}{2 \pi I k_{n}}+\frac{\ln \left(\frac{r_{n-1}}{b}\right)}{2 \pi L k_{n-1}}\right)^{-1}\left(T_{n}-T_{n-1}\right)
$$

In a simflar manrier, the heat conducted into zone a from zone $n+1$ is

$$
\dot{q}_{L}=-\left(\frac{\ln \left(\frac{a}{r_{n+1}}\right)}{2 \pi L k_{n+1}}+\frac{\ln \left(\frac{r_{n}}{a}\right)}{2 \pi L k_{n}}\right)^{-1}\left(T_{n}-T_{n+1}\right)
$$

The net heat gain per unit volume for zone $n$ becomea

$$
\frac{\dot{Q}_{R}+\dot{Q}_{L}}{\pi\left(b^{2}-a^{2}\right) L}
$$

Next, the time derlvaive of tenperature in equation (2) is approxdmated by the following standard difference operator: ${ }^{(1)}$

$$
\frac{\partial T_{n}}{\partial t}=\frac{T_{n}^{t+\Delta t}-T_{n}{ }^{t}}{\Delta t}
$$


The superscripts refer to time and the subscript refers to position.

Finaliy, the expressions in equations (10), (11), (12), and (13) can be combined In equation (i) and rearranged to give

$$
\begin{aligned}
T_{n}^{t+\Delta t}=T_{n}^{t} & +\frac{\Delta t}{\rho c} \frac{1}{\pi\left(b^{2}-a^{2}\right)}\left(\frac{\ln \left(\frac{a}{r_{n+1}}\right)}{2 \pi L k_{n+2}}+\frac{\ln \left(\frac{R_{a}}{a}\right)}{2 \pi k_{n}}\right)^{-1} \\
& +\frac{\Delta t}{\rho c} \frac{1}{\pi\left(b^{2}-a^{2}\right)}\left(\frac{\ln \left(\frac{b}{r_{n}}\right)}{2 \pi k_{n}}+\frac{\ln \left(\frac{r_{n-1}}{b}\right)}{2 \pi L k}\right)_{n-1}^{-2}\left(T_{n-1}-T_{n}\right)+\frac{\dot{q} \Delta t}{\rho c}
\end{aligned}
$$

Equation (14) can now be used to ealeulata the temperature of zone $n$ at time $t+\Delta t$. The solutions will be stable if the following condition 1s satisfled: (3)

$$
\Delta t<\frac{(\Delta r)^{2}}{2 \frac{k}{p c}}
$$

In addition, accuracy is improved as $\Delta t$ is reduced.

Boundary and Jource Terms

The source term, $\dot{j}$, in equation (..0) can be calculated for each zone. It is assumed that egch zone bas the seme voltage, $v$, applied across, $t$ during a glven time step. The heat generated per unit tine is given by

$$
\text { q VOL }=\frac{v^{2}}{\mathrm{R}}
$$

where $R 16$ the resiatance of the zone and VOL is the volume of the zone. $R$ can be calculated from

$$
R=\frac{1}{\sigma} \frac{\mathrm{L}}{\mathrm{A}}
$$

where $\sigma, L$ and $A$ are the conductivity, length, and cross-sectional area in the axdal direction, respectively. If Equation (17) 1s substituted into Equation (16), the source term becomes 


$$
\dot{q} \text { VOL }=\left(\frac{V}{L}\right)^{2} \sigma \text { VOL }
$$

In HTFLO, the applled voltage may be calculated in one of three ways. If the heating mode is by capacitive discharge, $\mathrm{V}$ ig the capacitor voltage. The total energy drained during a time steg is used to calrulate the voltage at the beginning of the next time step. Heating is terminated when the voltage falls below a predetermined value.

In the constant current mode, the sample': total resistance is calculated at each time step and the voltage determined from the product of current and resistance. In the voltage mode, a flxed resistor is assumed in series with the semple. As in the current moie, the sample's resiatence 18 calculated at each time step. The resilt is uged to determine the fraction of the applied voltage dropped acros the sample. In the current and voltage modes, heating is terminated after a specifled time has el apsed or the surface temperature reaches a set value,

The surface boundary term is radiation at flxed emssivity to a fixed heat alnk temperature. The surface temperature is calculated from the boundary condition of continuous heat flux. Flrat, the radiated power ia given by the Stefari-Boltimann equation:

$$
\dot{Q}=A \in \sigma\left(T^{4}-T_{s k}^{4}\right)
$$

where $A$ is the external surface area of the pin, $E$ is the emissivity, $\sigma$ the stefanBoltzmenn constant, $T$ is the surface temperature and $T_{s k}$ is the heat sink temperature. Following the technlque of Gabrielson et al. (1), equation (19) can be factored to give

$$
\dot{Q}=A \epsilon \sigma\left(T^{2}+T_{G k}^{2}\right)\left(T+T_{\theta k}\right)\left(T-T_{\theta k}\right) \cdot
$$

Th1s expression is made a linear function of the temperature difference between the surface and the heat sink for given time step by defining a surface heat transfer coefficient, $h_{R}$ :

$$
r_{R}=A \in \sigma\left(T^{2}+T_{B k}^{2}\right)\left(T+m_{s k}\right) .
$$


Second, the rate heat is conducted from the outermost zone to the surface 1s given by

$$
\dot{Q}=\mathrm{U}_{1}\left(\mathrm{~T}_{1}-\mathrm{T}\right)
$$

where $\mathrm{T}_{1}$ is the temperature of zone $1 . \mathrm{U}_{1}$ is deflned by

$$
\mathrm{U}_{1}=\frac{2 \pi L k_{1}}{\ln \left(\frac{\frac{D}{2}}{\frac{D}{2}-\frac{\Delta x}{2}}\right)} .
$$

where $T_{1}$ is the temperature of zone 1 . The boundary condition requires the two powers be equal.

$$
\mathrm{F}_{\mathrm{R}}\left(\mathrm{T}-\mathrm{T}_{\mathrm{sk}}\right)=\mathrm{U}_{1}\left(\mathrm{~T}_{1}-\mathrm{T}\right)
$$

Solving Equation (24) for the surface tenperature gives

$$
T=\frac{\mathrm{U}_{1} \mathrm{~T}_{1}+\mathrm{H}_{R} \mathrm{~T}_{\mathrm{ak}}}{\mathrm{U}_{1}+\mathrm{H}_{\mathrm{T}}} .
$$

The boundary condition between zones is the continuity of heat flux. At the center of the pin the heat flux is zero.

\section{Dynamic Heat Capacity Model}

Two heat capacity models for $\mathrm{UO}_{2}$ are shown in Flgure (2). Model 2 is based on measurements by standard calorlmetry methods with long heating and cooling t1mes. (4) Some recent transient vaporization experiments (5) suggest that model 1 , a linear extrapolation of the 1000-1500K ata from model 2, applies to rapid heating and coolIng processer.

HIFLO Incorporates a dynamic heat capacity model in which the instantaneous temperature $\mathrm{Mre}$ in response to a heat input is calculated using the linear heat capacity of model 1. Then, the temperature is relexed exponentially at constant enthalpy to the value given by the hest capacity of model 2. 


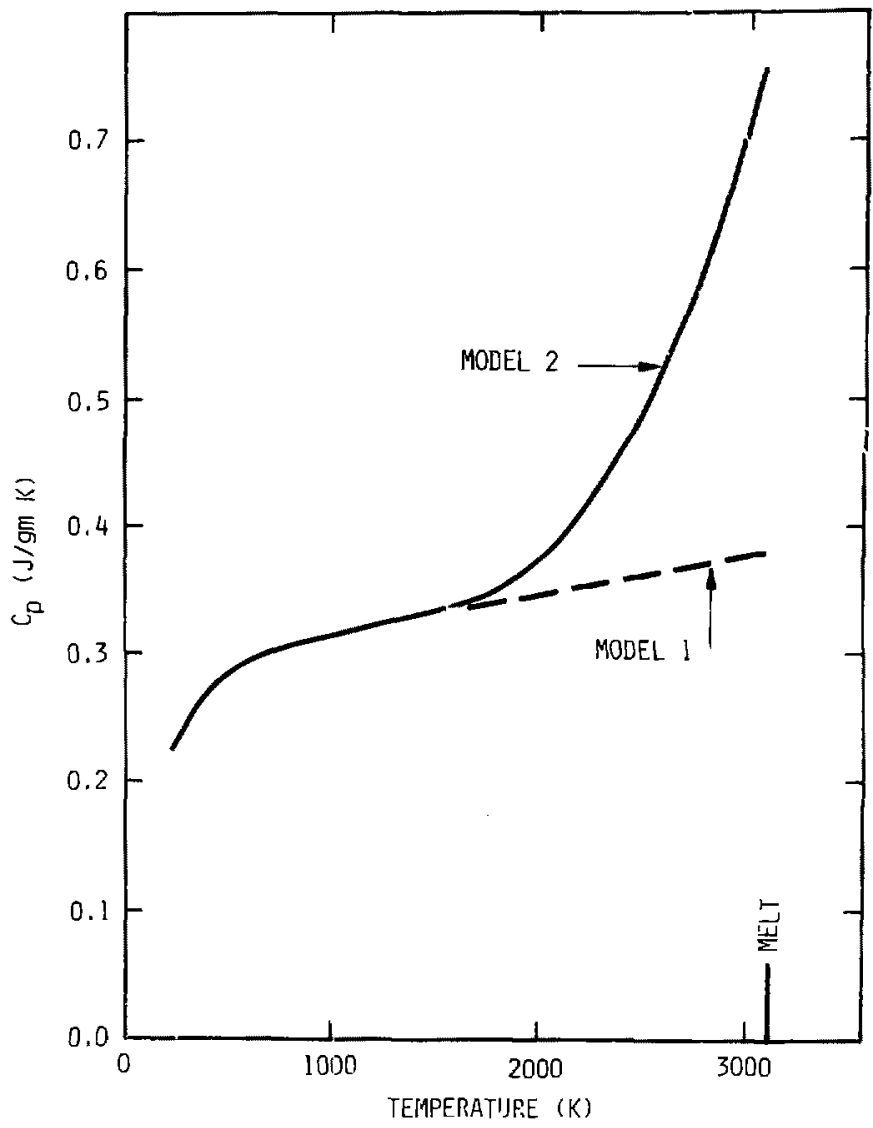

Flgure 2. Tho Models for the Heat Capacity of Solld Uר. 


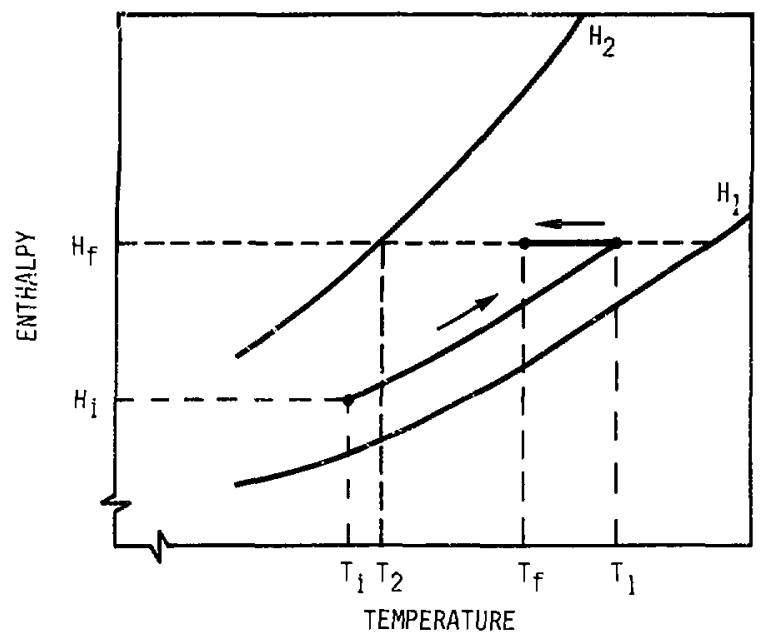

$\mathrm{H}_{l}$ : INSTANTANEOUS ENTHALPY, IEMPERATURE CURVE FOR MODEL I

$\mathrm{H}_{2}$ : EQLILIBRIUM ENTHALPY/TEMPERATURE CURVE FOR MODE!. 2

Figure 3. IIlustration of temperature/enthalpy history for one zone during a single time atep. 
Thj.s process is 1llustrated in Flgure 3. $H_{1}$ and $\mathrm{H}_{2}$ are the tempersture-enthalpy curves corresponding to heat capacity models 1 and 2 , respectively; $T_{i}$ and $H_{1}$ are the temperature and enthalpy of a Given zone at the start of a time step. A quantity of heat is added ralsing the enthalpy to $\mathrm{H}_{\mathrm{f}^{*}} \mathrm{~T}_{1}$ is the instantaneous temperature. $\mathrm{I}_{2}$ is the equiliorium temperature at enthalpy $\mathrm{H}_{f} . \mathrm{T}_{\mathrm{f}}$ is the flnal temperature for the tive step and is calculated by

$$
T_{f}=T_{1}-\left(T_{1}-T_{2}\right)\left(1-e^{-\Delta t / T}\right)
$$

where $A t$ is the length of the time step and $\tau$ is the relaxation time. 


\section{SAMF IE CALCULATION}

As the introduction stated, HWFL was developed to help assess the feasibility of a resistive heating experiment by simulativg various proposed conflgurations. The program is arranged, the refore, to set the ample gecmetry, emlsoiv.ty, initial temperuture anil heat sink temparature at the beginning of each calculation. Then, during the calculation, varlous heating modes can be set up to simulate the switching on of several different power supplies eeparatel by perass of pure heat conduction (no heating). Each of these periods 1s called a siparate heating period.

\section{FI'FLO Input Data}

The flrst cerd of tire data deck contatis the geometric information for the sample. The sample length (1a cm), diemeter ( $1 \mathrm{n} \mathrm{cm}$ ) and rumber of zones are required. The read stritement is in free format. This card is included only once regardless of the number of calculations to be performed in any given job.

The next card, aloo in free format, gives the following data:

1. The number of heating perfods in the calculation.

2. The surface emisaivity of the sample.

3. The heat sink temperature (in ${ }^{\circ} \mathrm{K}$ ).

4. The infial sample temperature--assumed spatially unfform (in ${ }^{\circ} \mathrm{K}$ ).

5. The heat capacity relaxation time (1n msec).

Thea, each heating perlod in the calculation requires a separate deta card using the format

$$
\text { FORMAT (2I5, 2F10.4, 2I5, 2F10.4). }
$$

The detalls of each input varlable are as follows:

1. HTFLAG - defines whether there is reslative heating during the period:

$$
\begin{aligned}
& 0 \text {, No heating } \\
& 1 \text {, Heating }
\end{aligned}
$$

2. LFLAG - deflnes the limiting condtition for terminating the perlod:

$$
\begin{aligned}
& \text {-1, Time Limit } \\
& \text { 0, Surface Temperature Limit } \\
& \text { 1, Gepacitor Voltage Limft }
\end{aligned}
$$


3. IIMTT - defines the limit spectfled by LFLAG (1n mgec, oK, or volts).

4. DEIT - the length of the time otep (in mser).

5. ITAR - the number of time steps per line of prissed output.

6. IFLAG - deflnes the tyre of power supply for hesting:

$$
\begin{aligned}
& -1 \text {, Constant Current } \\
& 0 \text {, Conetant Voltage } \\
& \perp \text {, Discherging capecitor }
\end{aligned}
$$

7. CURVOL - the power supply output for the current $\varepsilon$ n? vultage heating modes or the intitial cepacitor voltage for the discharging capacitor heating mode.

8. RESCAP - the resistor in series with the sample for the current and voltage modes o- the value of the capacitor for the discharging capacitor heating mode.

If HTFLAG $=0$ (1.e., no resistive heating), Inputs 6,7 and 8 are left blank.

HTFTO is currently dimensioned for up to 10 heating periods per calculation. Up to 24 calculations can bi perforned in one job by adding the appropriate data cards. The last card in the data aeck must have 1000 punched on it (free format).

output

HTFLO generates both tabulated output and plots. The tahulated output lists the temperatures at selected points in the sample at the end of the spectfled number of time steps. The total hest deposited in the aample since the start of the most recent hesting period (KTFLAG = 1) is also listed. This is followed by the heat capacity calculated from the total heat added and the change in surface temperature. Then, the heat capacities of models $I$ and 2 at the given surface temperature are shown. The final outputs compare the calculated and modeled heat capacities.

There are two plots generated for each selculation. The flrst shows the sample's temperature profile at the end of each heating perlog awi tne second shows the aurface temperature as a function of time during the calculation. 
APPERDIX A - THETMAL PROPERTIES OF $\mathrm{UO}_{2}$ USED IN HTFLO

1. Property: Themal Conductivity

Model: $\quad k=\left(4.0+2.57 \times 10^{-2} \mathrm{~T}\right)^{-1}+.72<10^{-12} \mathrm{~T}^{3}$

Untts: $\quad k=W / \mathrm{cm} n$

Source: Reference 4

2. Property: Density

Yodel: $\quad \rho=10.97\left(1.0+2.04 \times 10^{-5} \mathrm{~T}+8.7 \times 10^{-9} \mathrm{~T}^{2}\right)^{-1}$

Units: $\quad \rho=\mathrm{gm} / \mathrm{cm}^{3}$

$T={ }^{\circ} \mathrm{C}$

Source: Reference 4

3. Property: Speclflc Heat - Yodel 1

Model: $\quad C_{\mathrm{P}}=.2762+3.78 \times 10^{-5} \mathrm{~T}$

Untts: $\quad \mathrm{Cp}_{\mathrm{p}}=\mathrm{J} / \mathrm{gm}^{\mathrm{o}} \mathrm{K}$

$\mathrm{T}={ }^{\circ} \mathrm{K}$

Source: Linear extrapolation of speciflc heat from the range of $1000^{\circ} \mathrm{K}$ to $1500^{\circ} \mathrm{K}$ in RePerence 4

4. Property: Electrical Conductivity

Model: $\quad$ in $\sigma=-3 \times 10^{-9}-2011.8 / \mathrm{T} ; \mathrm{T}<1400^{\circ} \mathrm{K}$

in $\sigma=9.58-15235 / \mathrm{T} ; \mathrm{T}>1400^{\circ} \mathrm{K}$

Units: $\quad \sigma=\Omega^{-1} \mathrm{~cm}^{-1}$

$\mathrm{T}={ }^{\circ} \mathrm{K}$

Source: Reference 6

5. Property: Enthalpy - Equilibrium Model

Model: $\quad$ II $=32.6897+\frac{158.778}{e^{535 / T}-1}+1.21675 \times 10^{-5} T^{2}$

$$
+87420 e^{-18939.7 / T}
$$

Units: $\quad \mathrm{H}=\mathrm{J} / \mathrm{gm}$

$\mathrm{T}={ }^{\circ} \mathrm{K}$

Source: Reference 4 
6. Property: Equiltbrium Temperature

Model: $\quad T=-53.9406+4.66449 \mathrm{gl}-2.08141 \times 10^{-3} \mathrm{H}^{2}$

$+3.52908 \times 10^{-7} \mathrm{~K}^{3}$

Units: $\quad T={ }^{\circ} \mathrm{K}$

$\mathrm{H}=\mathrm{J} / \mathrm{gm}$

Source: Polynomial flt to enthalpy in Reference 4

7. Property: Specif1c Heat - Model 2

Madel: $\quad C \mathrm{~g}=.22999-.153147 \times 10^{-3} \mathrm{~T}+.494636 \times 10^{-7} \mathrm{~T}^{2}$

infts: $\quad \sigma p=J / g m$ or

$\mathrm{T}=\mathrm{OK}$

Source: Reference 4 
APPENDIX B - FORTRAN LISTING OF HTFLO FOR CDC 7600 . 
PROGRAP HTFIO T6/7G OPT=2 FTN $4.6+4524$

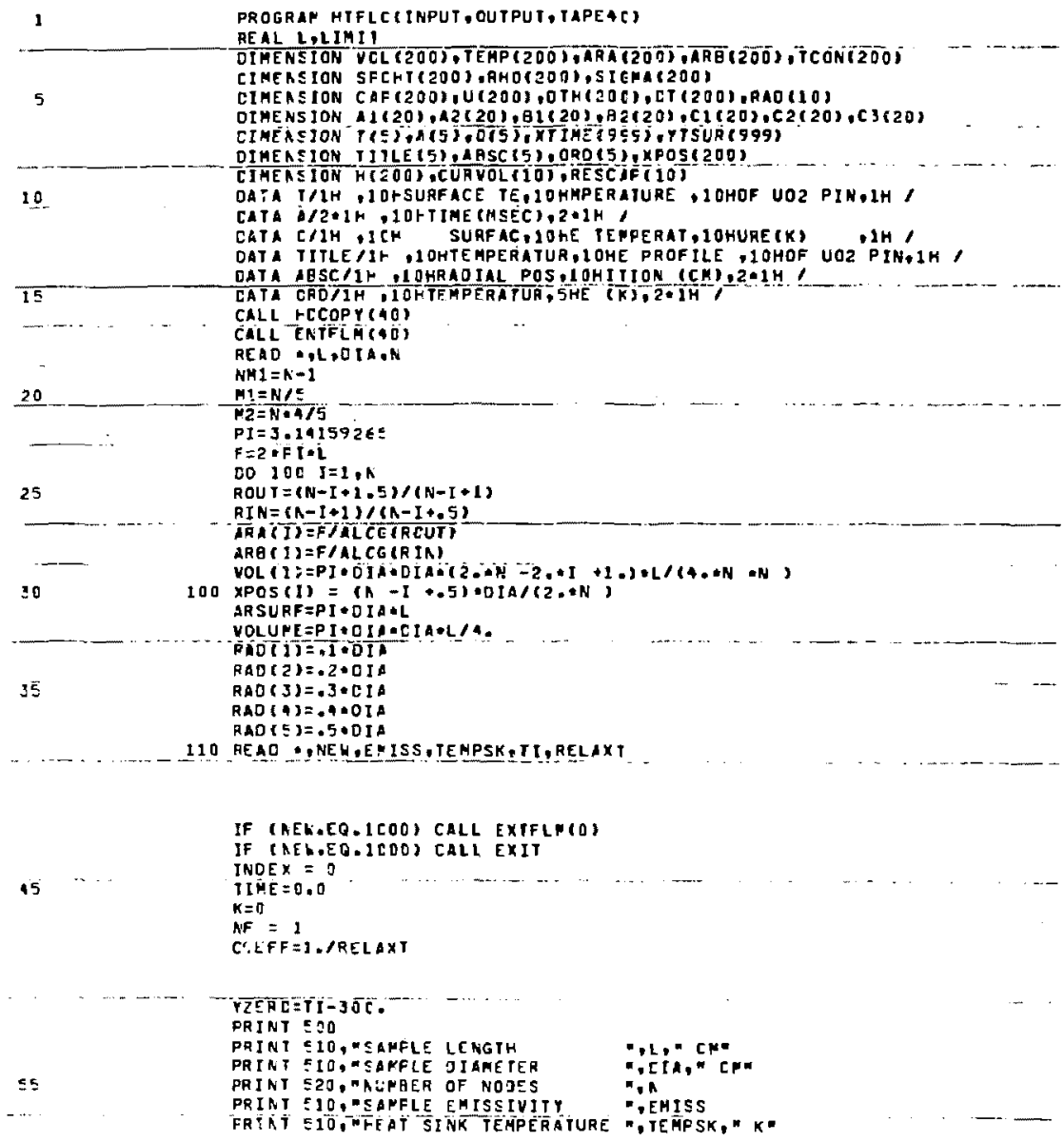


115

PRINT 700

PRINT E2O,T]YE,IERP(S), TTEMP(N-I),IEMI, M2,MI), TENFSUA

XTIME $(K)=T$ TIFE

YTSUR (K) $=$ TERF SUR

120

c

CALCULATE THERMAL PROPERTIES

$160 \quad P=0$

$170 \mathrm{M}=\mathrm{M}+1$

SUR: $=0$.

125

$00210 I=1, \mathrm{~h}$

C

THERNAL CONCLCTIVITY (ICON)

(ii $/[M K)$

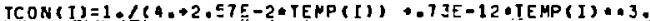

130

C CENSITY (RHC)

(EM/CC)

$T 1=T E N P(I)-27 \Xi$.

$R 1=1 .+2 \cdot 04 E-5+T 1 \cdot 8 \cdot 7 E-9 \cdot T 1 \cdot T 1$

$R H O(I)=10.97 / R 1$

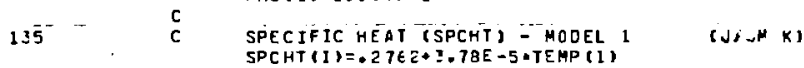

C HEAT CAPACITY (CAP)

$(J / x)$

CAP $(I)=\operatorname{VOL}(I) \cdot S P C H T(I)=R H O(I)$

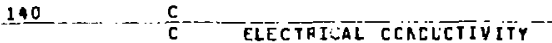
IF (TEFF (I) - 1400,) 190,190,200

190 ELNS I $=-3, E-9-2011.8 / T E M P$ (I)

SIGKAII) $=$ EXP (ELNSIG)

145 GO TC 210

200 ELNSIG $=9.58-152 \times 5 . / T E H P(I)$

STGMA(I)=EXF(ELNSTG)

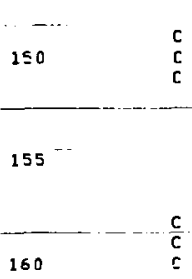

210 SUH $=$ SUP+SIGPA (I) VVOL (I)

C CACLULATE HEAT THANSFER CCEFFICIEATS

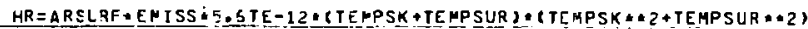
DO $220 \quad I=2, A$

$C I=1 . /(A R A(I)+T C C N(I-I))$

$C 2=1 .,($ ARB $(I) \cdot$ TCDN $(I))$

$220 \mathrm{U}(\mathrm{I})=1 \cdot 1(\mathrm{D} 1+C 2)$

U(2) = ARA (1) * TCCN(1)

CAL CULATE HEAT INPUTT FAOH RESISTIVË HEATJNG -

IF (HTFLAG) $\geq 40,340,230$

230 IF (IFLAG) $2 \leq 0,255,2 \leq 0$

25C RES $=L \cdot L /$ SUH

$V 1=[L F V O L\{] A[E X\} * R E S$

165

$v_{2}=v_{1} \cdot v_{1}$

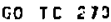

255 RES $=L+L / S L F$

$V_{1}=$ CLRVOL (INCEX)*RES/(RESCAP(INCEX)+RES

170

$V_{2}=V_{1}+v_{1}$

GO TC $\approx 70$

260 V2 $=E+E$ (RESCAP(INOEX)*1+E-6) 


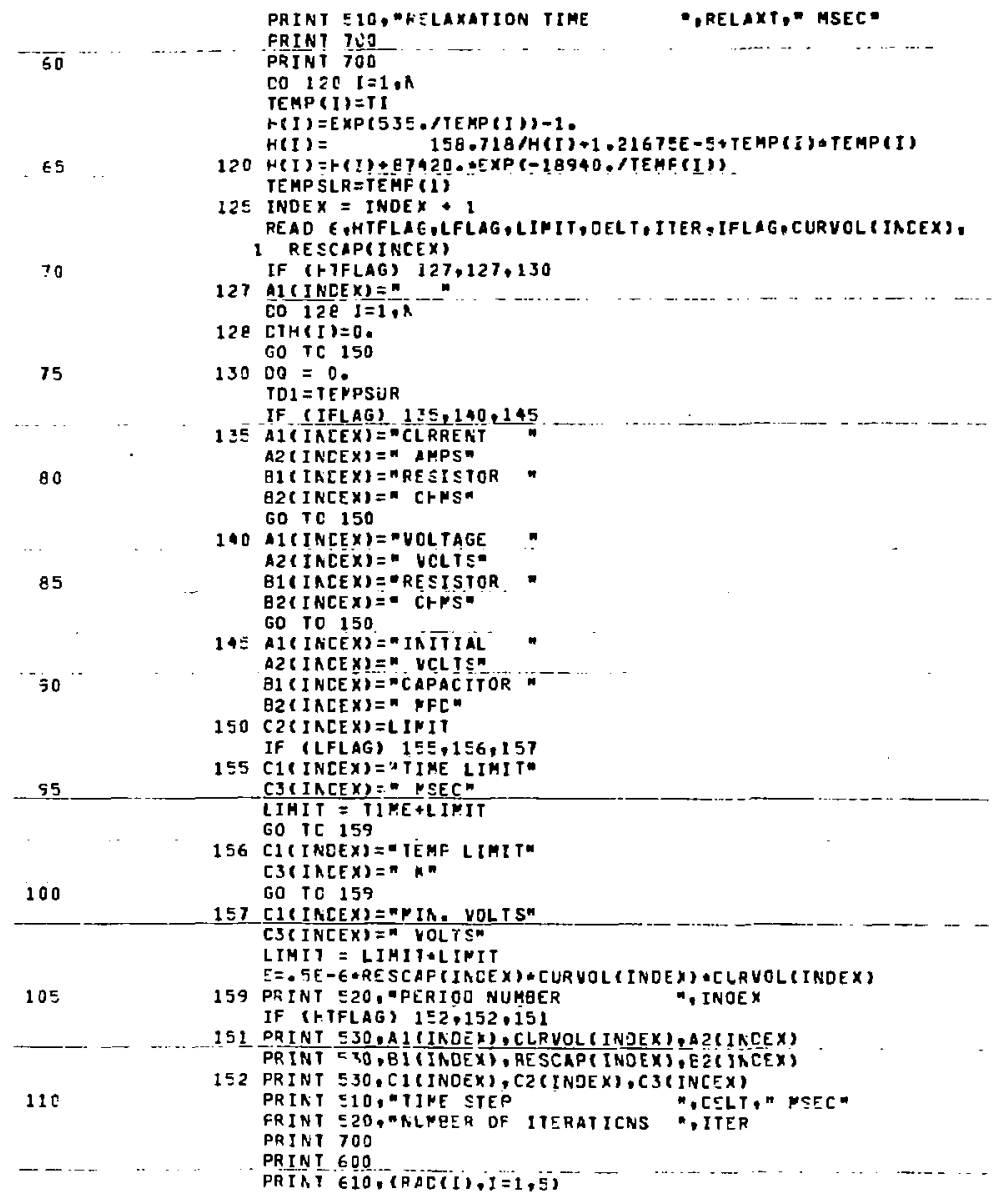


PROGPAP HTFLO 76/76 CPT=2 FTN $4.6 \$ 452 A$

175

IF (V2-LIMIT) $470,470,270$

270 . $2028 \mathrm{Q}$

CTH $(I)=V D+S I \in H A(I)=Y O L(I) /(L \cdot L)$

$180 \quad$ C

$O E=D T H(I)+O E L T+1 \cdot E-3$

$E=E-C E$

$280 \quad C O=D C+C E$

C CALCULATE HEAT FLOH

340 TEMP SLR $=(H R+T E M P S K+U(1)+T E P P(1)) /(H A+U(1))$

$\operatorname{Or}(1)=\operatorname{L}(1)+(\operatorname{TENPSUR}-\operatorname{TEMP}(1))+U(2) \cdot(\operatorname{TEAP}(2)-\operatorname{TEMP}(1))$

$00350 \quad I=2, N H 1$

$350 \mathrm{CT}(I)=L(I)+(1 E F P(I-1)-T E M P(I))+U(I+1)+(T E M P(J+1)-\operatorname{TEMP}(I)$

185. $\quad D T(N)=L(N)=(I E N P(N-1)-T E M P(N))$

C CALC. NEW TEPP. DUE TO RESISTIVE HEATING ANE HEAT FLON

CO $380 \quad I=1, A$

190

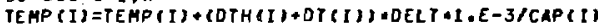

-

$195360 \mathrm{CH}=(\mathrm{CI}(1)+0 \mathrm{IH}(1))+D E L T+1, E-3 /(\mathrm{VOL}(\mathrm{I}) \cdot \mathrm{AHO}(I))$

$r(1)=r(I)+D r$

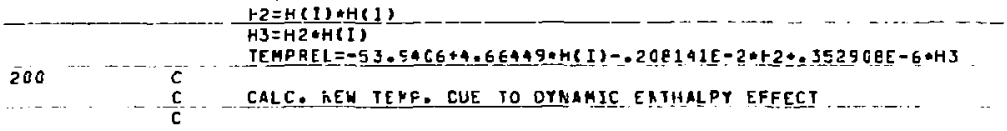

$205 \quad$ FACTCF $=$ EXP(-COEFF + CELT $)$

TERP(1)=(TENF(I)-TEMPREL ) \&FACTOR + TE HPAEL

370 IF (TENP(I)-3138.) $380,380,420$

380 CONT TALE

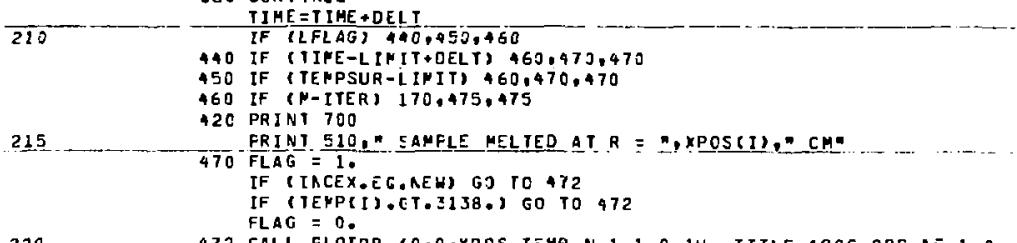

220

472 CALL FLOTPR $10,0, X P O S, T E 4 A, N, 1,1,0,1 H$, IITLE,ABSC,ORE,AF, $1,0,1$

$1, F A C(5), 1, Y Z E R D, 3200, ?$ $A F=D$

GO TC 180

$225 \quad 480$ CP=CGITEMPSLA-TOL)

CPCALC $=$ SPCHT II P VOLUPE *RHOLI)

$D C=(C F-C P C A L C)=100 . / C P C A L C$

ANLCP $=.22999-.253147 E-3+T E M P S U R+.45463 E E-7$ TTE HPSUR TEMPSUR 


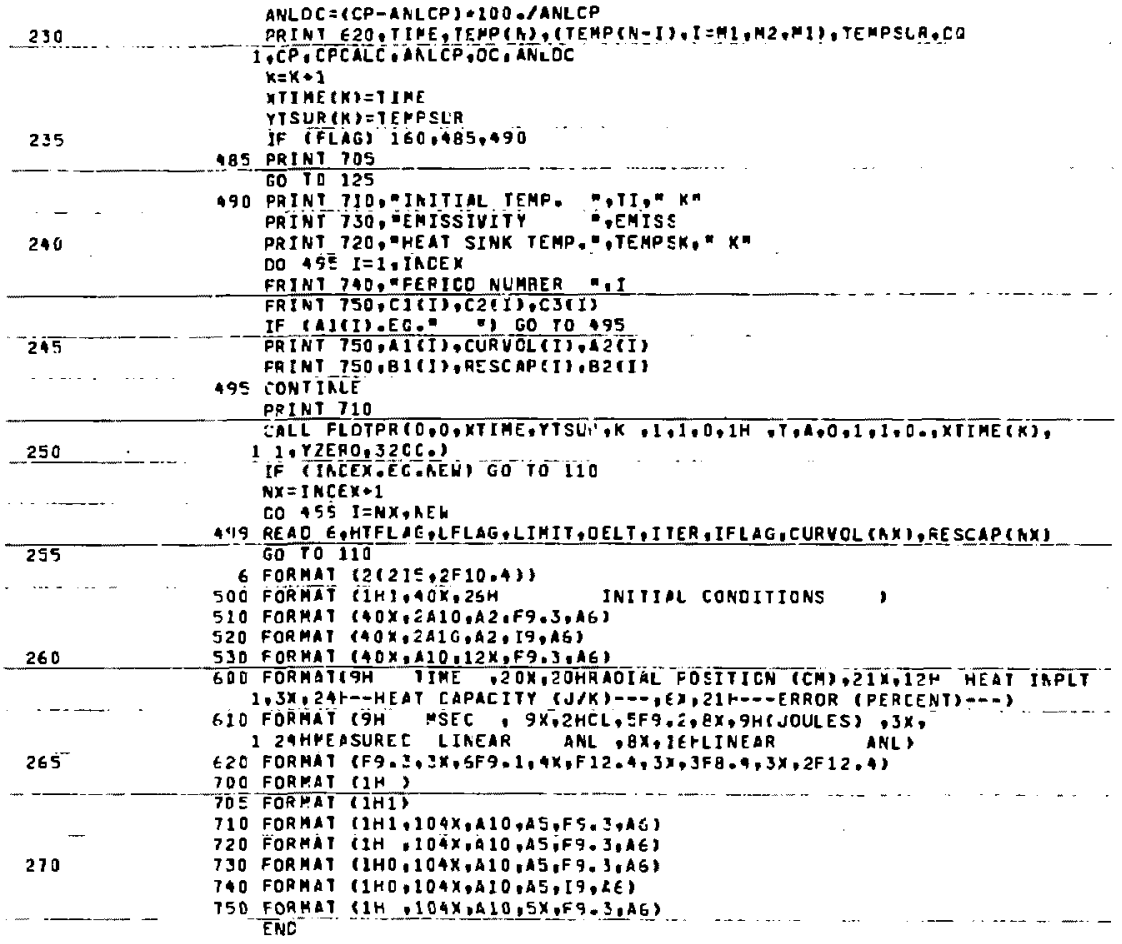




\section{APPERDIX C - SAMPLE CALCULATION UBIMG HTFLO.}

The sample calculation was done for a total of six beating periods: three active and three pasaive. The flrat perled wamed the anple to $2000^{\circ} \mathrm{F}$ rith a high voltage power supply, followed by a $150 \mathrm{msec}$ perlod with no sctive heat ingut. The third period held the gample's gurface temperature at a fafrly constant value for 1 aecond wth a low voltage power supply. The fourth perlad wes another period without active heating which lasted for 500 mgec. The fifth period heated the gemple rapldiy with a discherging capacitor as the power source. The final perlod, lagting for 1.5 ste inds, had no active heating and the sample cooled by surface radiation.

The data cards for this calculation are listed in Flgure 4. The computer output listing is show following the flgure. 


\section{DATA CARDS FOR SAMPLE HTFLO CALCULATION}

11111111112222222222333333333344444444445555555355666666666677777777778 12245678901234567890123456789012345678901234567890123456789012345678901234567890

C SAMPLE

SAMPLE

NUMBER

C LENGTH

DI AMETER

OF ZONES

1 .

.2

50

CARD 1

C NUMAER OF

SIIRFACE

HEAT SINK

$C$ PERIONS

EMISSIVITY

TEMPERATURE

DEG $K$

6

$$
.2
$$

300 .

TEMPERATURE TIME

DEG $\mathrm{K}$ MSEC

300 .

100.

CAFD 2

C HTFLAG LFLAG Li HIT DELT ITER

$\begin{array}{rrlll}1 & 0 & 2000 . & .2 & 500 \\ 0 & -1 & 150 . & .2 & 200 \\ 1 & -1 & 1000, & .02 & 500 \\ 0 & -1 & 500 . & .05 & 200 \\ 1 & 1 & 10 . & .02 & 50 \\ 0 & -1 & 1500, & .05 & 200\end{array}$

IFLAG CURVOL RESCAP

0 1000. 50.

012.

1.272

1400.

BOO.

CARD 3

CARD 4

CARD 5

CARD 6

CARO 7

CARD 8

C LAST DATA CARD

1000

LAS ICARD

11111111112222222222353333333244444444445555555555666666666677777777778 $1234 b 67890123456789012345678901234567 \mathrm{~A}>01234367890123456789012345678901234567890$

Flgure 4. Imput data cards for the sample Hirfo caleulation, colum numbers are shown to 11 lustrate the required format. 


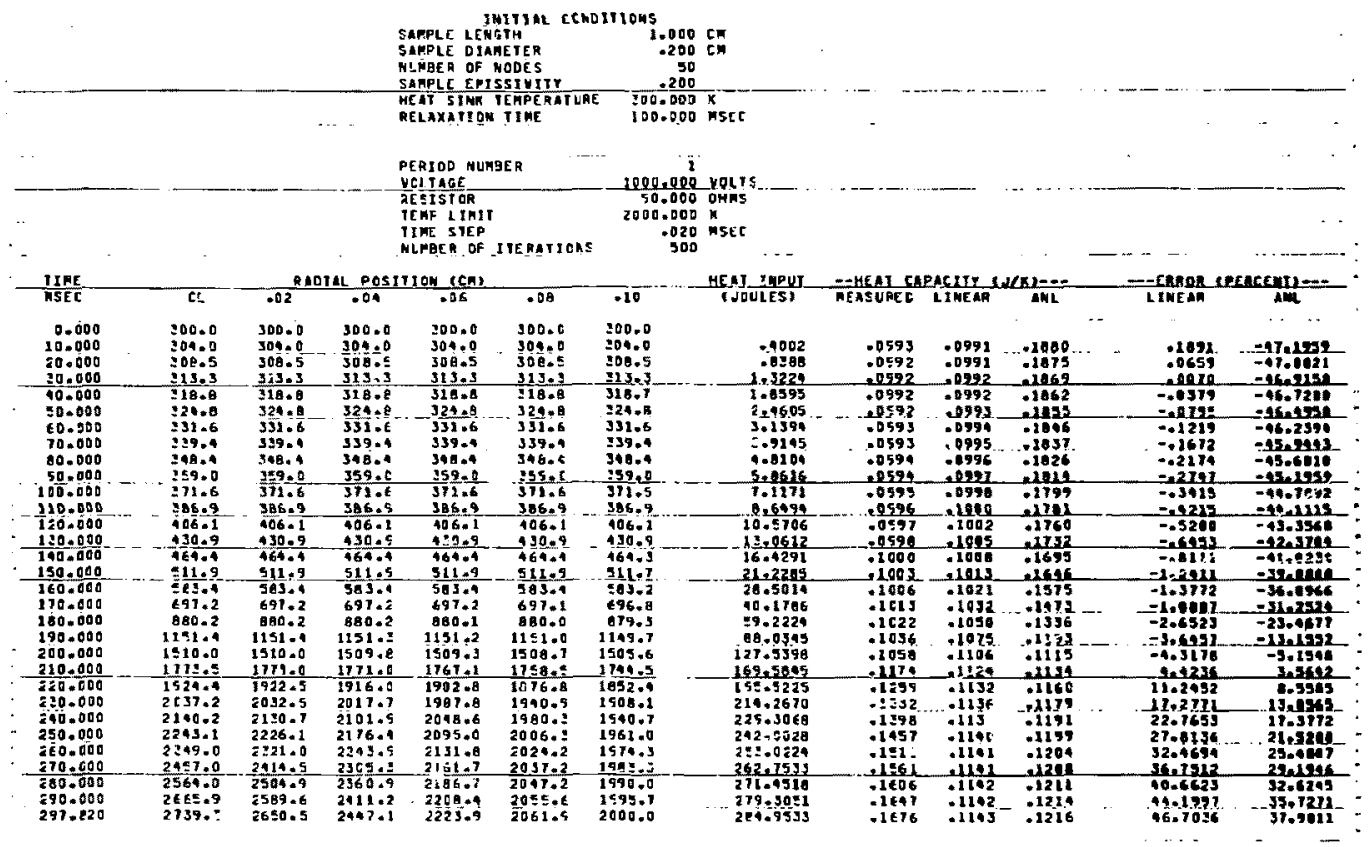




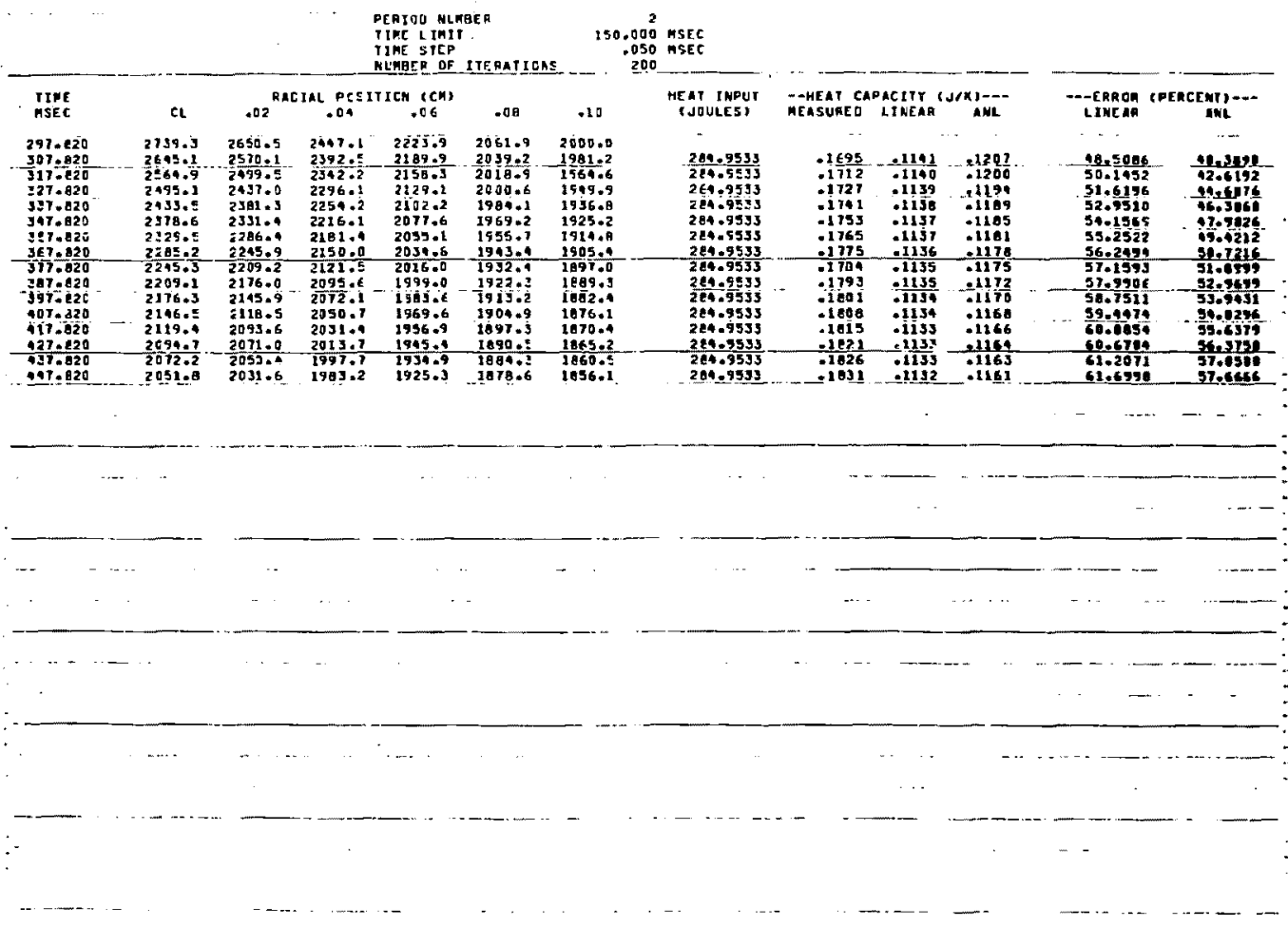




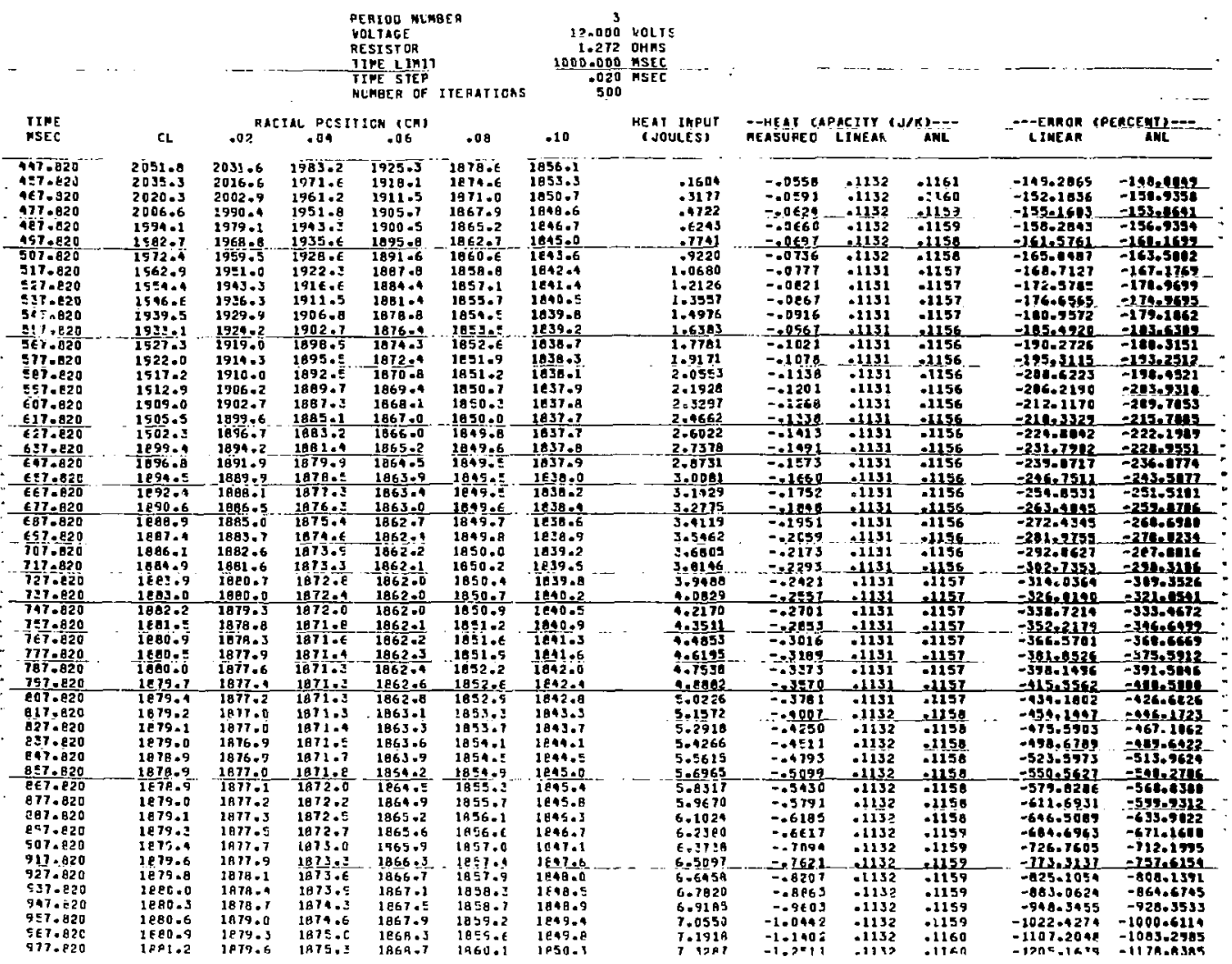




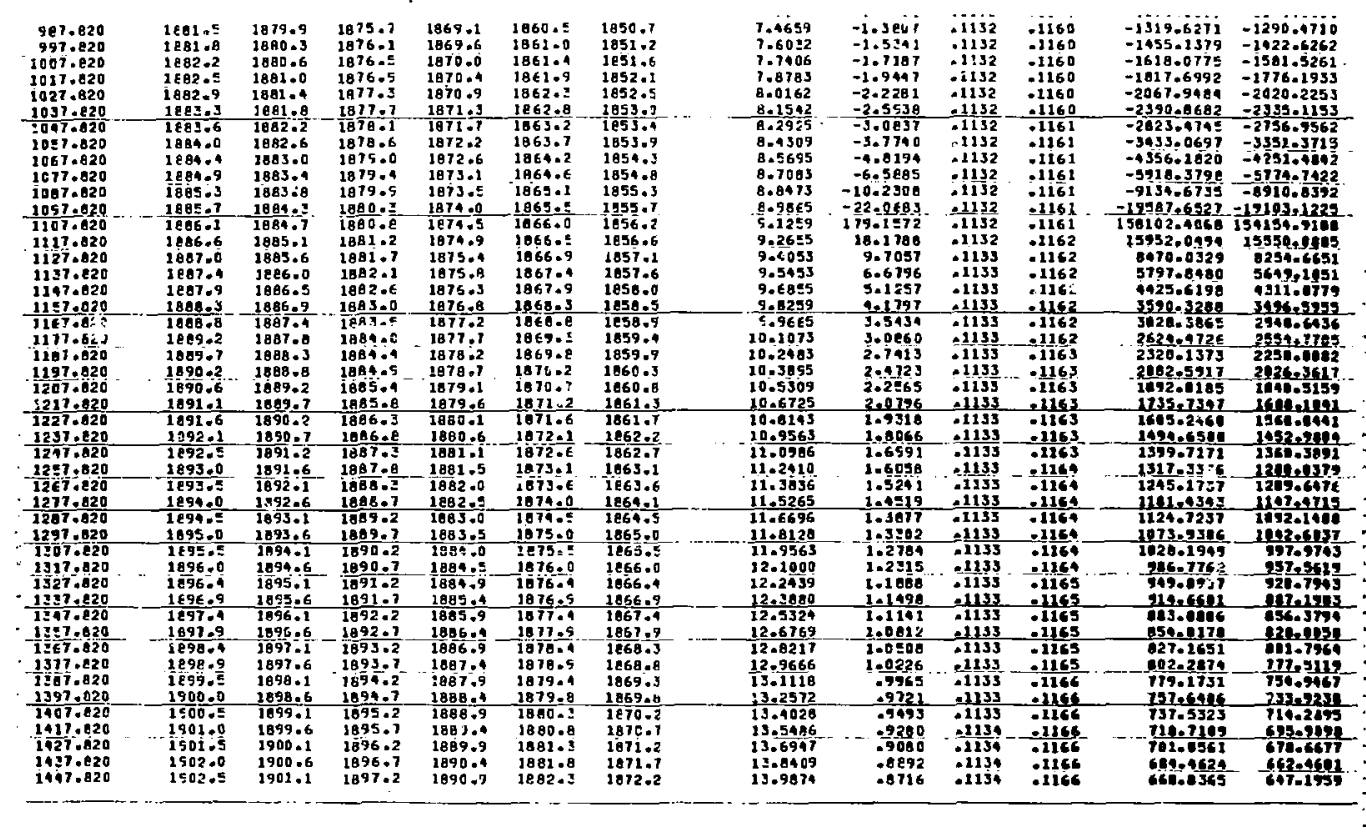




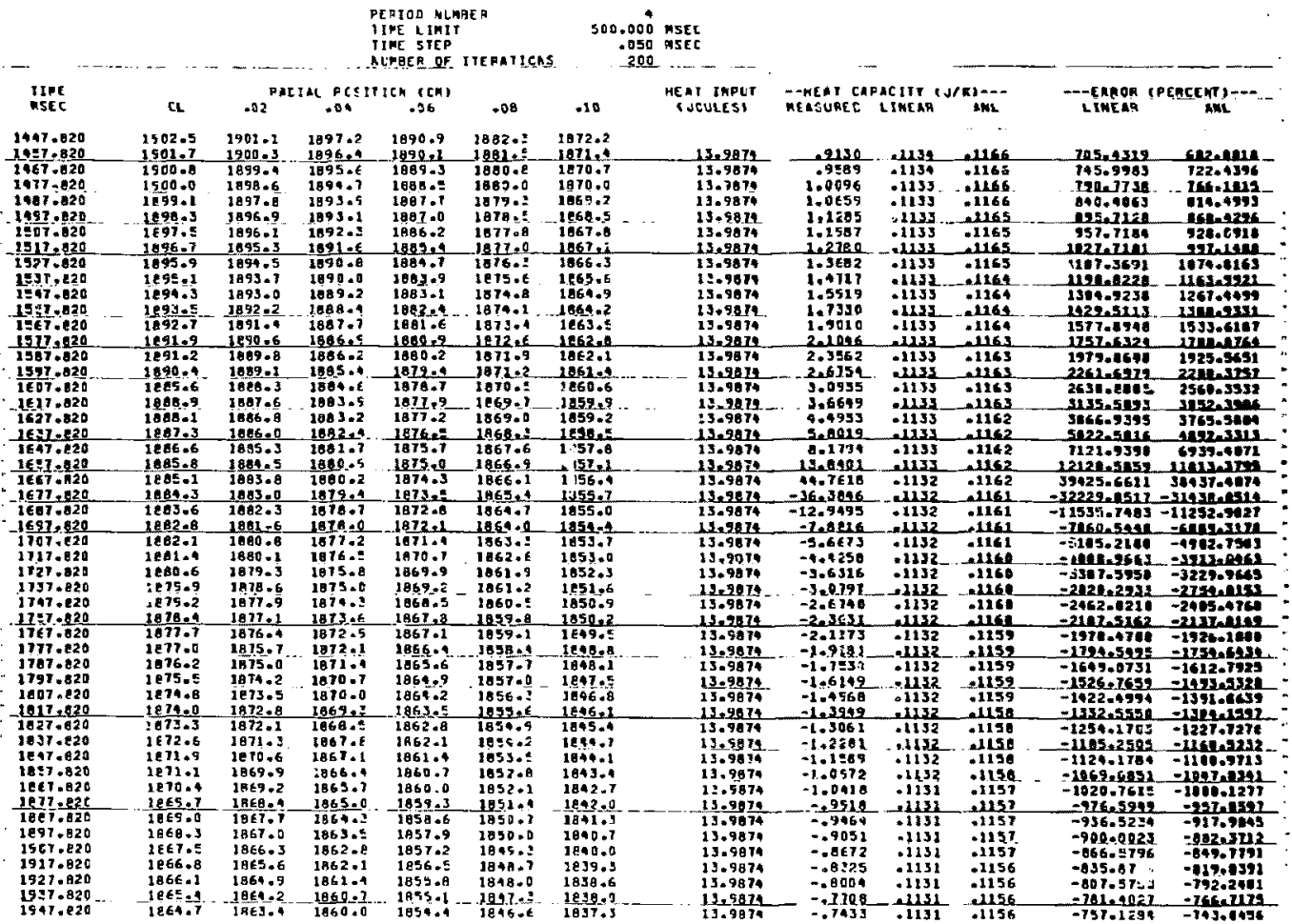




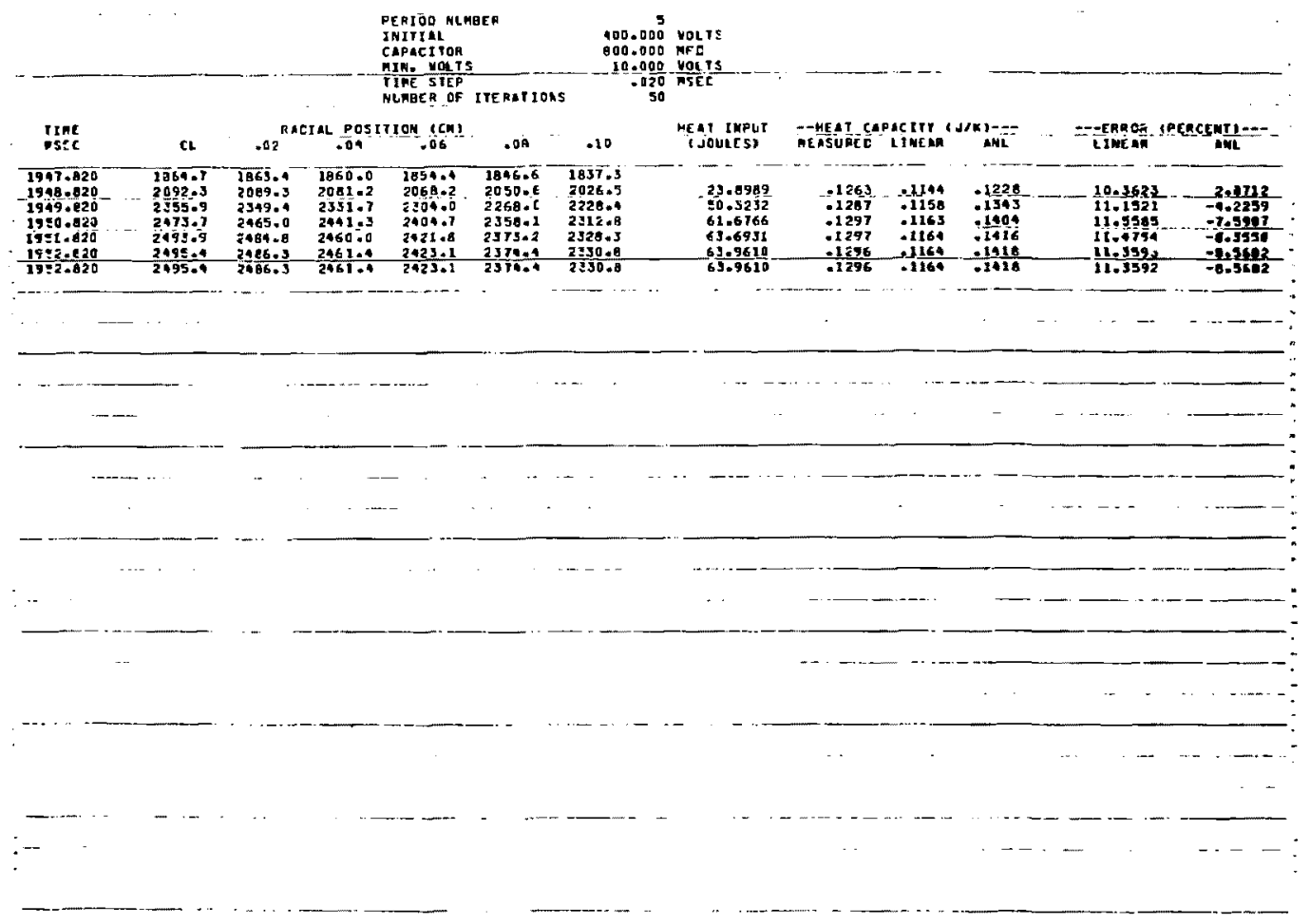




\begin{tabular}{|c|c|c|c|c|c|c|c|c|c|c|c|c|}
\hline - & & .. & & 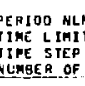 & & $\begin{array}{r}1500.000 \\
-\quad 050 \\
-\quad 200 \\
\end{array}$ & $\begin{array}{l}\text { MSEC } \\
\text { MSEC } \\
-\ldots .-\end{array}$ & & & & & \\
\hline 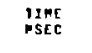 & $\mathrm{CL}$ & .02 & $\begin{array}{l}\text { AL } P C S \\
.04\end{array}$ & $\begin{array}{c}\mathrm{ICN}(\mathrm{CM}) \\
.06\end{array}$ & . 98 & .10 & $\begin{array}{l}\text { MEAT INPUT } \\
\text { (JOULES) }\end{array}$ & $\begin{array}{l}\text {--meai cap } \\
\text { measufed }\end{array}$ & 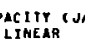 & K) & $\begin{array}{l}- \text {-ERFOA C } \\
\text { LINEAR }\end{array}$ & II:-- \\
\hline $\begin{array}{l}1952.020 \\
15 \in 2.820\end{array}$ & $\begin{array}{l}245 \leq .44 \\
2432.8\end{array}$ & 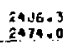 & $\begin{array}{l}2461.4 \\
2450.2\end{array}$ & $\begin{array}{r}2423.1 \\
2413.3\end{array}$ & $\begin{array}{l}2514.4 \\
2360+c\end{array}$ & $\begin{array}{l}2530.7 \\
2332: 0\end{array}$ & & & & & & \\
\hline 1972.820 & $2471=1$ & 2462.7 & 2439.8 & 2409.6 & 2353.2 & $2330=6$ & 63.9610 & 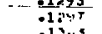 & :1169: & -1417 & $\begin{array}{l}1180.119 \\
31.1119\end{array}$ & 1177 \\
\hline $\begin{array}{l}1582.820 \\
1592.820\end{array}$ & $\begin{array}{l}2460.4 \\
240.5\end{array}$ & $\begin{array}{l}2+52,3 \\
24+2.3\end{array}$ & $\begin{array}{l}2430.2 \\
2421.8\end{array}$ & $\begin{array}{l}2396.9 \\
290.2\end{array}$ & $\begin{array}{l}2358.8 \\
2350.8\end{array}$ & $\begin{array}{l}2328.3 \\
2 \geq 25.8\end{array}$ & 68.9610 & -1ะus & -1164 & .1016 & 11.9314 & -7.9971. \\
\hline 2002.820 & $2441+3$ & 2933.0 & 2413.7 & $\begin{array}{l}2390.2 \\
\varepsilon \geq 84.0\end{array}$ & $2 \geq 52.0$ & $\begin{array}{l}2353.8 \\
2323.0\end{array}$ & $\begin{array}{l}63.9610 \\
63.9610\end{array}$ & $\begin{array}{l}-1309 \\
.1317\end{array}$ & 0 & $9+149$ & $\begin{array}{l}12.596= \\
13.1828\end{array}$ & 年 \\
\hline $2012-829$ & 2432.9 & 6425.7 & 2006.4 & 2378.5 & 2391.4 & 2320.3 & 69.9610 & .1324 & .1163 & 年1409 & 19.0467 & 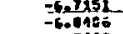 \\
\hline$\frac{-20 \div 2.820}{2032.820}$ & $\frac{2425.0}{2417 \cdot A}$ & $\frac{31 A_{-2}}{211.3}$ & $\frac{2399.5}{739.5}$ & $\frac{297364}{2368}$ & $\frac{73}{834} \frac{3.5}{0.7}$ & $\frac{2317.5}{2314.8}$ & 67.9610 & .1332 & .1163 & .1407 & Ik.5146. & \\
\hline $2042 \times 820$ & 2411.2 & 2404.9 & $2388 \cdot 4$ & $\begin{array}{l}2368.88 \\
2369.5\end{array}$ & 2337.5 & $\begin{array}{r}2-1148 \\
2312-2\end{array}$ & $\begin{array}{l}8.9610 \\
63.9620\end{array}$ & $\begin{aligned} 1239 \\
-1349\end{aligned}$ & -1163 & :1405 & 25.1785 & -4.6117 \\
\hline 2052.820 & $240=0$ & 2359.1 & 2383.2 & 2960.5 & ESa.e & 2309.6 & 69.9610 & : & $\begin{array}{l}-1163 \\
.1169\end{array}$ & $\begin{array}{l}:_{1403}^{1403} \\
.1401\end{array}$ & $\begin{array}{l}15.8335 \\
16.4765\end{array}$ & (223) \\
\hline $\begin{array}{l}20 \leq 2.220 \\
2072.820\end{array}$ & 2599.4 & $\begin{array}{r}8393.7 \\
2389.7\end{array}$ & $2379 . \epsilon$ & 2356.8 & 2331.7 & $2307-2$ & & $0.1 \div 61$ & .1162 & -1399 & $27=2059$ & $\begin{array}{l}3.3699 \\
\text { entule }\end{array}$ \\
\hline $\begin{array}{l}2072.820 \\
2082.020\end{array}$ & $\begin{array}{l}2394.11 \\
2399-3\end{array}$ & $\begin{array}{r}2380.7 \\
3394.0\end{array}$ & $\begin{array}{l}2374.5 \\
2370.2\end{array}$ & 2333.4 & $\begin{array}{r}2329.0 \\
33326.4\end{array}$ & $\begin{array}{l}2304.8 \\
2302.5\end{array}$ & 63.9610 & -1368 & $\because 162$ & $\begin{array}{l}-1398 \\
-1396 .\end{array}$ & 17.7206 & 2.2116? \\
\hline 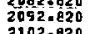 & $\frac{2389.3}{2384.8}$ & $\frac{2384=0}{2379.7}$ & $\frac{2370 \cdot 2}{2366 \cdot 5}$ & $\frac{2350.2}{2: 47.0}$ & $\begin{array}{l}-3325: 4 \\
-392 \leq-9\end{array}$ & $\frac{2302.5}{2300 \cdot 2}$ & $\begin{array}{l}6.9620 \\
E 3.9610\end{array}$ & $\begin{array}{l}1315 \\
.1302 \\
302\end{array}$ & $\begin{array}{c}.1162 \\
.1162\end{array}$ & -1396. & $\begin{array}{l}18.3205 \\
18.9062\end{array}$ & 告, \\
\hline $\begin{array}{l}.820 \\
.820\end{array}$ & $\begin{array}{l}22800.6 \\
2726.6\end{array}$ & E375.7 & 23630. & $2594 \div 11$ & 2321.5 & 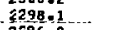 & 693610 & . 1.280 & 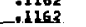 & $\begin{array}{l}11324 \\
.1323\end{array}$ & $\begin{array}{l}11.9062 \\
19.9112\end{array}$ & $\begin{array}{l}=.99448 \\
=3247\end{array}$ \\
\hline $\begin{array}{l}820 \\
820\end{array}$ & $\begin{array}{l}2376.7 \\
2313.0\end{array}$ & 2372.9 & & 2311.4 & 2319.3 & $2296=0$ & 69.9610 & $-8 \pm 95$ & .1162 & $\begin{array}{l}.1391 \\
-1391\end{array}$ & 20.0394 & $=\frac{.32415}{.2415}$ \\
\hline $\begin{array}{l}2172.820 \\
219.020\end{array}$ & $\begin{array}{l}2373.0 \\
2369.6\end{array}$ & $\begin{array}{l}2568.5 \\
235.2\end{array}$ & 56.6 & 2338.8 & $2317 \cdot c$ & 2294.0 & 63.9610. & .1901 & .1162 & -1390 & 20.5784 & .7923 \\
\hline$\frac{2142=020}{32+3030}$ & $2366 ; 3$ & $\begin{array}{r}2365.2 \\
2362.1\end{array}$ & $\begin{array}{l}2353.7 \\
2550.5\end{array}$ & $\begin{array}{r}2336.3 \\
2393.9 \\
\end{array}$ & $\begin{array}{r}2314.99 \\
23,209\end{array}$ & $\begin{array}{l}2299200 \\
2290.2\end{array}$ & $\begin{array}{l}6.9610 \\
63.9610\end{array}$ & $\begin{array}{l}1407 \\
: 1+13\end{array}$ & $\begin{array}{l}1162 \\
: 1161\end{array}$ & -1388 & 21.1099 & 1.3519 \\
\hline 7172.200 & 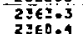 & $-\frac{5}{2539.2}$ & $2340 . \bar{z}$ & 8531.6 & 2310.5 & 2280.3 & 69.9610 & .1418 & .1161 & .1385 & $\frac{2126250}{22.1385}$ & $\frac{10.376}{2.3747}$ \\
\hline & $\begin{array}{l}2 \geq \in 0.4 \\
2 \geq 95.7\end{array}$ & $2356 \cdot 4$ & 2345.7 & -2329.5 & $=2=090$ & $\begin{array}{r}2286,5 \\
-230.5\end{array}$ & $62 \times 9620$ & s.1.24 & 0.1161 & .2384 & $22=6378$ & 2.Mines \\
\hline & $\begin{array}{l}2357.7 \\
2 \leq 55.1\end{array}$ & 2353.0 & $\begin{array}{l}2343, \sqrt{Z} \\
2392,0\end{array}$ & 7327.3 & $\begin{array}{l}2307.1 \\
2305.3\end{array}$ & $22 \theta 4.7$ & 65.9610 & -1430 & .1161 & $13 B 3$ & 29.1275 & 3.3768 \\
\hline 2152.820 & $\begin{array}{l}2737.1 \\
2352.6\end{array}$ & $\begin{array}{l}2351.3 \\
234.9\end{array}$ & $\begin{array}{l}2341.0 \\
2338 . \bar{E}\end{array}$ & $\begin{aligned}-2325.3 \\
2323.3\end{aligned}$ & $\begin{array}{l}2305.3 \\
2303.5\end{array}$ & $\begin{array}{l}2293.0 \\
2281.4\end{array}$ & $\begin{array}{l}64 \times 9610 \\
63.9610\end{array}$ & : & $\underbrace{.1161}_{1161}$ & $\frac{1982}{.1380}$ & 23.6046 & \\
\hline 2202.820 & $2 \geq 50.2$ & 2346 36 & $\frac{23}{23} 6.7$ & $2321 \cdot 4$ & 2304.6 & $2219=7$. & 63.9620 & $\begin{array}{l}-1940 \\
-2996 \\
\end{array}$ & $\begin{array}{l}1161 \\
-1162 \\
\end{array}$ & $\begin{array}{l}1.1380 \\
.2375 ; \\
.04\end{array}$ & 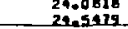 & 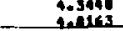 \\
\hline $\begin{array}{l}2212.820 \\
2222.826\end{array}$ & $\begin{array}{l}2547.9 \\
2: 4=.7\end{array}$ & $\begin{array}{l}2344.19 \\
2342.2\end{array}$ & $\begin{array}{l}2334.4 \\
2332.7\end{array}$ & & $\begin{array}{l}2300.1 \\
2250.0\end{array}$ & & 65.9610 & .1451 & .161 & -1378 & 25.0076 & 5.2428 \\
\hline 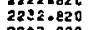 & 239.66 & $\begin{array}{l}2342.2 \\
2390.2\end{array}$ & $\begin{array}{l}2332.7 \\
2330.7\end{array}$ & 2317.00 & $\begin{array}{l}2250.05 \\
z 296.5\end{array}$ & $\begin{array}{l}22766.6 \\
2275.1\end{array}$ & $\begin{array}{l}6.9610 \\
E 9.9610\end{array}$ & $\begin{array}{r}-1456 \\
: 1461\end{array}$ & $\begin{array}{l}1161 \\
.1160\end{array}$ & $\begin{array}{l}-1377 \\
-1376\end{array}$ & $\begin{array}{l}25.9614 \\
25,9099\end{array}$ & \\
\hline $\begin{aligned} 2292.820 \\
22: 200\end{aligned}$ & 2341.6 & 2338.2 & $\begin{array}{r}2328.5 \\
2327\end{array}$ & 2314.3 & 2295.3 & 2273.5 & (63.9610 & $\begin{array}{l}.1461 \\
.1966\end{array}$ & .1160 & $\begin{array}{l}0 \\
-1375\end{array}$ & $\begin{array}{l}25.9099 \\
26.3531\end{array}$ & $\begin{array}{l}6.100 \\
\text { f. }\end{array}$ \\
\hline & $\begin{array}{l}2339.6 \\
2330.7\end{array}$ & $\begin{array}{l}2396.2 \\
2334.3\end{array}$ & $\begin{array}{l}2327 \cdot c \\
2325 .\end{array}$ & $\begin{array}{l}2312 \cdot 6 \\
2 \geq 11.0\end{array}$ & $\begin{array}{l}2293+7 \\
2292.2\end{array}$ & $\begin{array}{l}2272.1 \\
2270-1\end{array}$ & $\begin{array}{l}6.9610 \\
63.9510\end{array}$ & $=1471$ & $\begin{array}{l}1160 \\
-1160\end{array}$ & - 1374 & $2 \in=79$ & fosest \\
\hline & & $\frac{2534: 3}{25320.5}$ & 2323.5 & $\frac{2}{2309.0}$ & 2290.7 & $\frac{2270.6}{2269.2}$ & $\begin{array}{c}\frac{5.3510}{6.9610} \\
6.9610\end{array}$ & $\frac{.197 t}{.1481}$ & 11160 & $\frac{1.1373}{.1372}$ & $\frac{27.253}{27.6526}$ & \\
\hline & & 2330.7 & $2321=0$ & 2301.8 & 2289.2 & $\begin{array}{l}2269.02 \\
2251.8\end{array}$ & 63.9610 & $\begin{array}{l}1 \\
-14986 \\
\end{array}$ & .1160 & $\begin{array}{l}-1372 \\
.1371\end{array}$ & & 53 \\
\hline & & & & 66.2 & & $2 \geq 66.4$ & 65.9610 & .149 & .1160 & .23 & $\begin{array}{l}88.5193 \\
28.53\end{array}$ & 0.8912 \\
\hline & $2 \geq 30 \cdot 4$ & & 8.5 & 2309.7 & 2286.3 & 2265.0 & 63.9510 & -1996 & .1160 & & 28.9597 & \\
\hline $\begin{array}{l}2312.820 \\
2,152.620\end{array}$ & & 2325.5 & & & 2284.9 & $\begin{array}{l}2263.6 \\
2262.3\end{array}$ & $63.9610^{-}$ & $\begin{array}{l}-1500 \\
0=05\end{array}$ & -1160 & .1368 & 29.8663 & 7 \\
\hline $2+2.220$ & $232=.4$ & $2322 \cdot 3$ & 2313.7 & 2500.2 & $\frac{4}{2282.0}$ & $\frac{26620.5}{2260.5}$ & $\frac{63.5610}{63.9610}$ & -1.1505 & $\frac{1160}{.1160}$ & . & $\frac{29.7905}{30.2115}$ & \\
\hline & 2523.7 & 2320.7 & $2312=2$ & 2298.7 & 2280.6 & 2259.6 & $\in 3,9610$ & .1515 & .1160 & .1365 & 30.6317 & \\
\hline & & $2: 19,1$ & 2319.7 & 2297.3 & ह279.3 & 2258.3 & 63.9613 & $-1 \leq 19$ & .1159 & .1564 & 31.0513 & 11.4603 \\
\hline & $\begin{array}{l}2325.0 \\
3315.0\end{array}$ & $\begin{array}{l}2317.5 \\
8316=0\end{array}$ & $\begin{array}{l}2309 . \overline{3} \\
2307 . \overline{7}\end{array}$ & z295.d & $\begin{array}{l}2217.5 \\
0276.5\end{array}$ & $\begin{array}{l}2255.9 \\
0=55=8\end{array}$ & 63.9610 & $-1 \leqslant 24$ & .1159 & $\cdot 1363$ & 51.4 & \\
\hline 238 & $\begin{array}{l}2 \leq 1500 \\
2\end{array}$ & 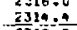 & $\begin{array}{r}2306.2 \\
\end{array}$ & $\begin{array}{r}22993: 0 \\
-2293\end{array}$ & 2215.2 & $\begin{array}{r}2250.6 \\
2254.3\end{array}$ & $\begin{array}{r}63.9620 \\
63.96\end{array}$ & $\begin{array}{r}-1529 \\
: 1534 \\
1-30\end{array}$ & $\begin{array}{r}1159 \\
-1159 \\
-119\end{array}$ & $\begin{array}{l}-1362 \\
: 2362 \\
: 236\end{array}$ & $\begin{array}{l}31.0895 \\
320.3005\end{array}$ & $\begin{array}{l}22.2411 \\
32.6119\end{array}$ \\
\hline $\begin{array}{l}219.820 \\
2 \cos 2\end{array}$ & 27159 & 2512.9 & & 2241.6 & 2273.8 & 2253.1 & 62.9610 & .1538 & .1159 & .1360 & 32.7211 & 13.0550 \\
\hline $\begin{array}{l}2002.2020 \\
2412.220\end{array}$ & $\begin{array}{l}2 \geq 21949 \\
2 \geq 12.9\end{array}$ & 年 & $\begin{array}{r}2303.8 \\
2301.0\end{array}$ & 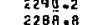 & & & & $\begin{aligned} 1543 \\
0\end{aligned}$ & .1159 & & & \\
\hline & $2 \geq 11.4$ & 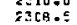 & 3300.0 & 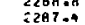 & 2259.5 & & $\begin{array}{l}3.9610 \\
\in \Xi-9610\end{array}$ & $\begin{array}{l}1 \leq 48 \\
-1 \leq 53\end{array}$ & $\begin{array}{r}1139 \\
: 1159\end{array}$ & .135? & 33.5 & 13.9496 \\
\hline $.82 C$ & $2 \geq 05,9$ & $z \geq 07.00$ & 2299.0 & $22 \mathrm{AB} .1$ & 2268.6 & $2=48.0$ & & $.1 \leq 58$ & $\begin{array}{l}11157 \\
.1159\end{array}$ & :1358 & & $\begin{array}{l}14.3693 \\
14.7958\end{array}$ \\
\hline & $2309=5$ & 3505.6 & & 254.7 & -2367 & 2246.1 & & c. 562 & A1159 & .21356 & & \\
\hline .820 & $2 \div 07.0$ & 2304.1 & & $\varepsilon \geq 83.4$ & 2asE=0 & 2245.7 & 63.9610 & .1567 & .1199 & .135 & & \\
\hline & & & & $\varepsilon 282$ & & & & & & & & \\
\hline & & & & 2280.7 & 226 & & & & & & & \\
\hline $15 z=226$ & $2 \geq 01.3$ & $\begin{array}{l}2299.9 \\
2298 \div\end{array}$ & $\begin{array}{l}2292.00 \\
2290.7\end{array}$ & $\begin{array}{l}2579.3 \\
2879.0\end{array}$ & $\begin{array}{l}2262.1 \\
3260.8\end{array}$ & $\begin{array}{l}2291.7 \\
z \bar{z}+0 . E\end{array}$ & 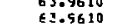 & $\begin{array}{r}1582 \\
: 1596\end{array}$ & $\begin{array}{l}\$ 1158 \\
: 1158\end{array}$ & $\begin{array}{r}1352 \\
: 1552\end{array}$ & $\begin{array}{l}36.5318 \\
36.4600\end{array}$ & $\begin{array}{l}16+9405 \\
17 \times 375:\end{array}$ \\
\hline & $2 \approx 59.9$ & & & $=376-7$ & & $=:=39.5$ & $\alpha=.0<11$ & 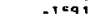 & . 1דן & $\therefore-a 1$ & १7. र & הanpan \\
\hline
\end{tabular}




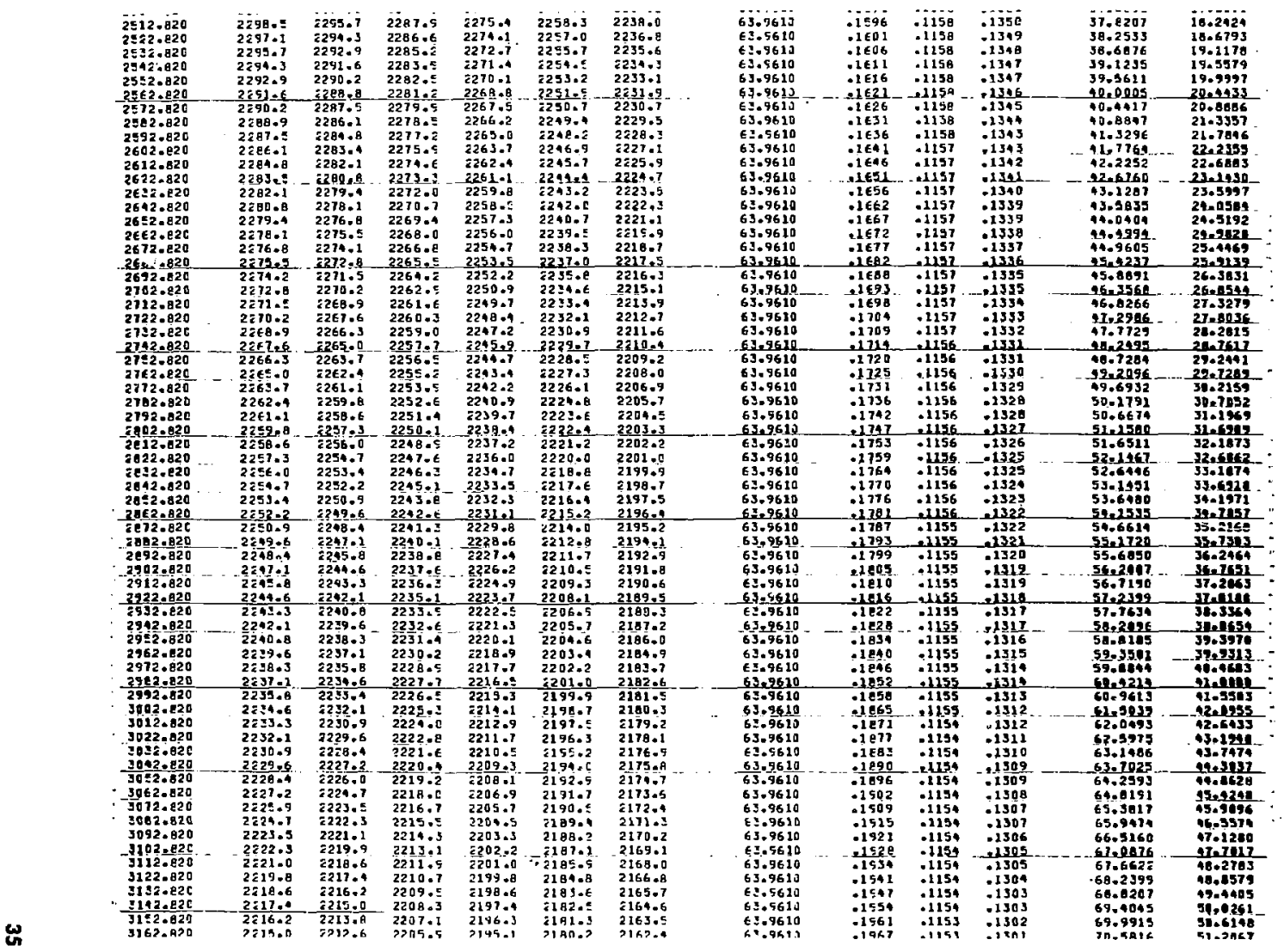




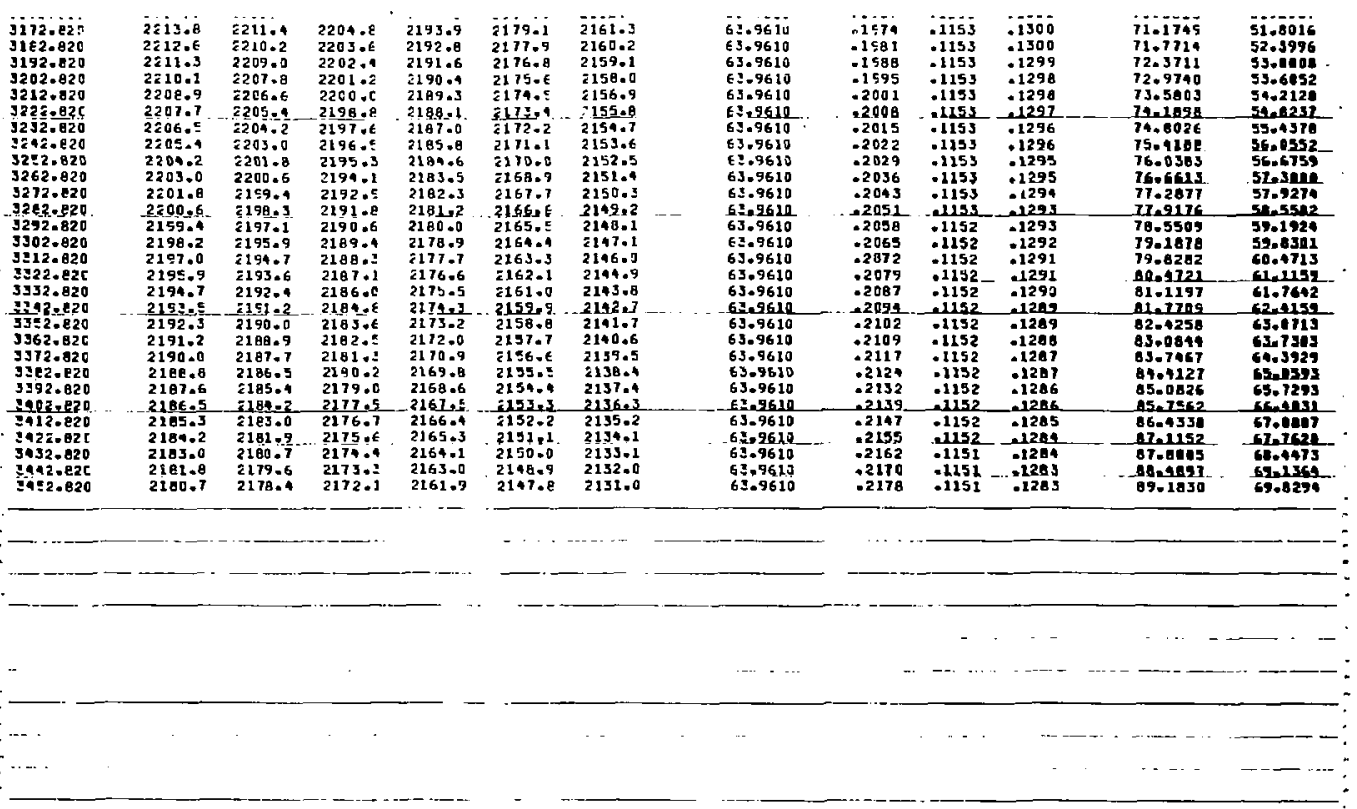




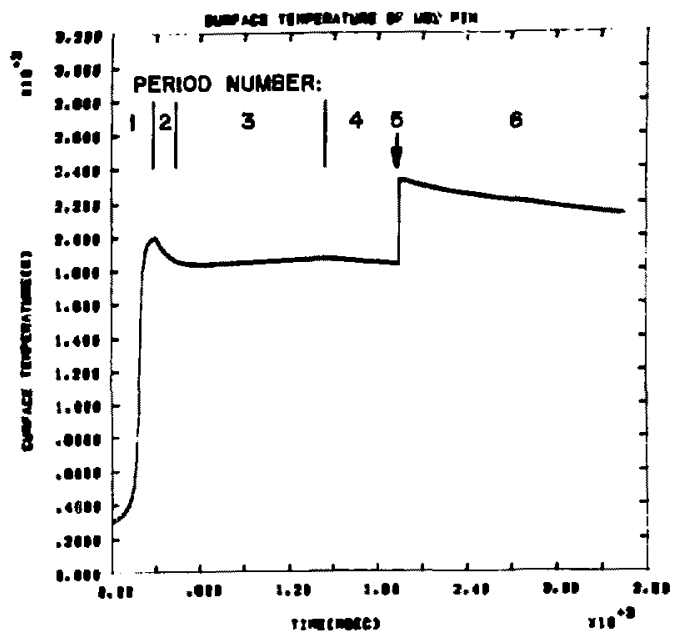

\begin{tabular}{|c|c|c|}
\hline 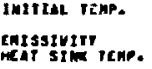 & $\begin{array}{r}300.000 \\
300.2000\end{array}$ & x \\
\hline 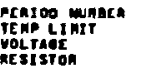 & $\begin{array}{r}2000.008 \\
1040.000 \\
51.000\end{array}$ & 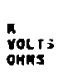 \\
\hline $\begin{array}{l}\text { Penjod munack } \\
\text { TInE LIMIT }\end{array}$ & $150.000^{2}$ & nsec \\
\hline 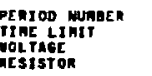 & $\begin{array}{r}1000.009 \\
12.090 \\
1.212\end{array}$ & $\begin{array}{l}\text { msec } \\
\text { vat Ts } \\
\text { OHAs }\end{array}$ \\
\hline 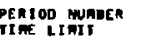 & 500.000 & MSEC \\
\hline 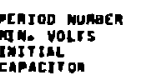 & $\begin{array}{r}10.000 \\
100.000 \\
000.000\end{array}$ & $\begin{array}{l}\text { volis } \\
\text { volts } \\
\text { wfo } 0\end{array}$ \\
\hline $\begin{array}{l}\text { penjod munash } \\
\text { TIAE LIMIT }\end{array}$ & 1500.0006 & nsec \\
\hline
\end{tabular}

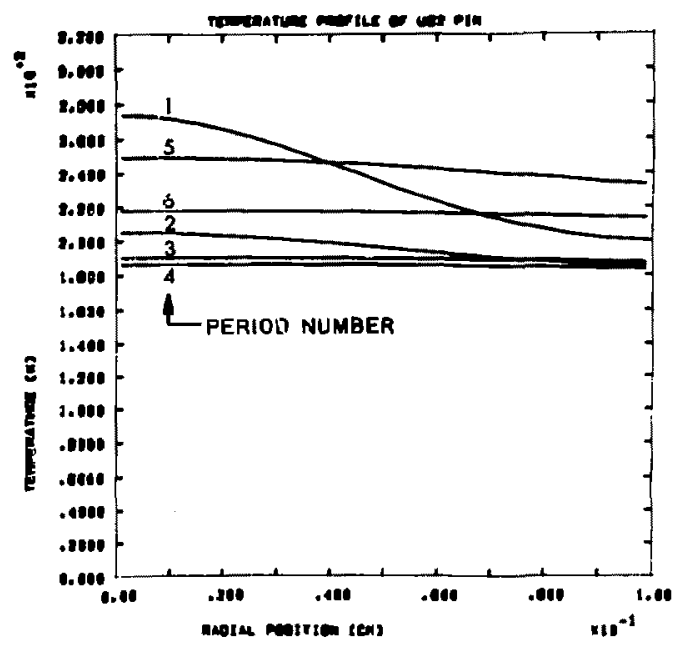


1. V. K. Gabrielson, B. W. Grange and K. D. Chrlstian, ONEDM - A Computer Code for Solving One-Dimengional Noaltnear Heat Transfer Problema, Sandia Iabs Report SCL-DR-69-99, Sandia Laboratorles, Albuquerque, NM, Februery, 1970.

2. E. G. Bergeron, Theoretical Congideretions of Rate Effecta in UO, Sanda Labs Report SAND78-1745, Sendia Laboratorles, Albuquerque, IN, February, 1979.

3. H. S. Carslaw and J. C. Jaeger, Conduction of Heat in Bolfds (Oxford Univeraity Press, Oxford, 1976).

4. L. IJebowltz, Chmn., Properties for IMFBR Safety AnalyB16, Argonne Nationel Lab Report ANL-CWN-RSD-76-1, Argonne National Lab, Argonne, II, March, 1976.

5. D. A. Benson, Application of Pulsed Electron Beam Vepord zation to Studies of UO 2 , Sandia Labs Report SAND77-0429, Sandia Laboratorles, Albuquerque, NM, June, 1977.

6. J. I. Bates, C. A. HInmen and T. Kawada, Am. Cer. Soc., 50, 652 (1967). 